
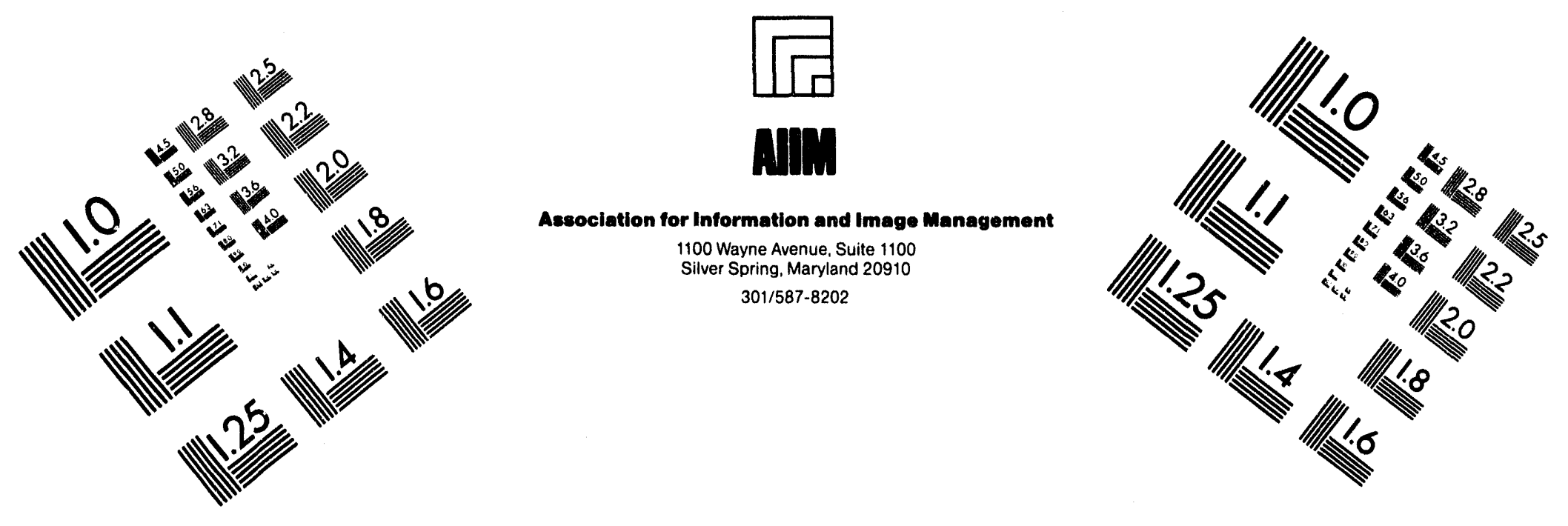

\title{
Centimeter
}

|

Inches
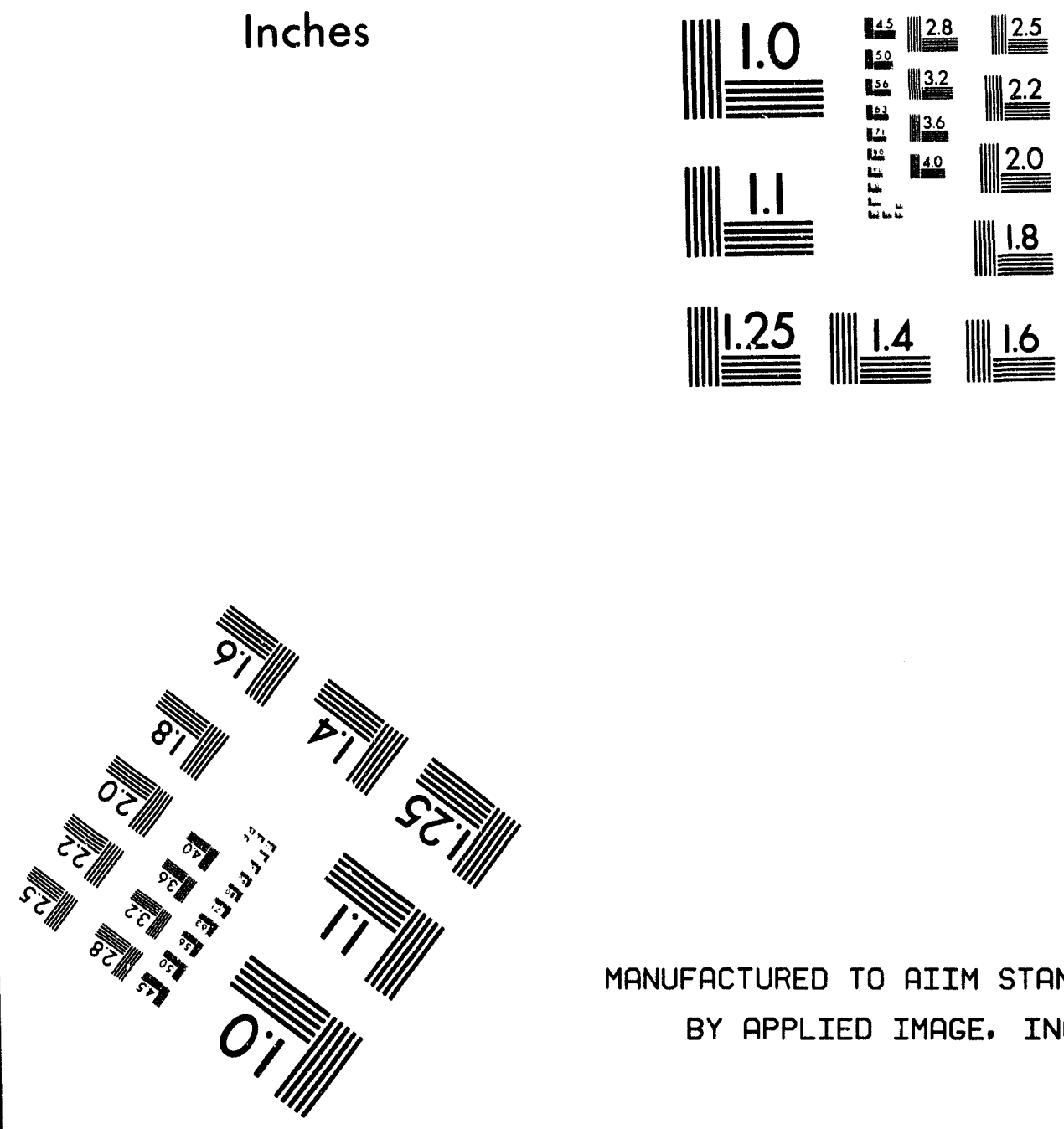

MANUFACTURED TO AIIM STANDARDS

BY APPLIED IMAGE, INC.

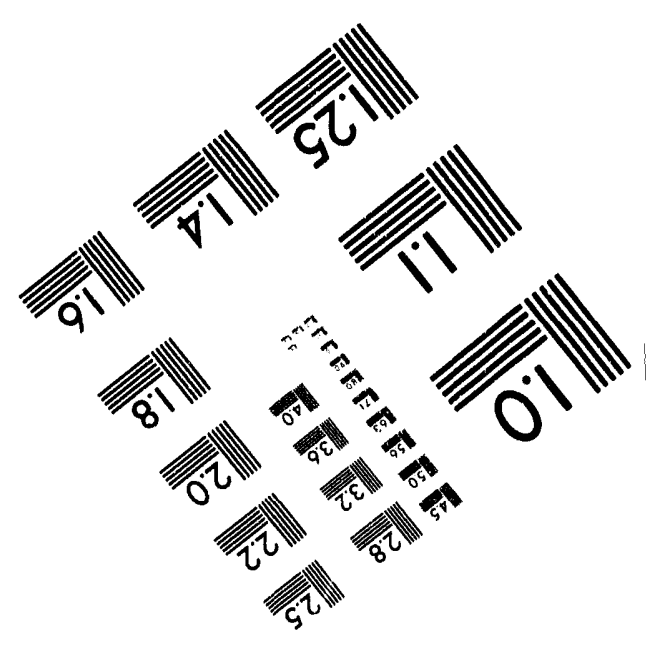



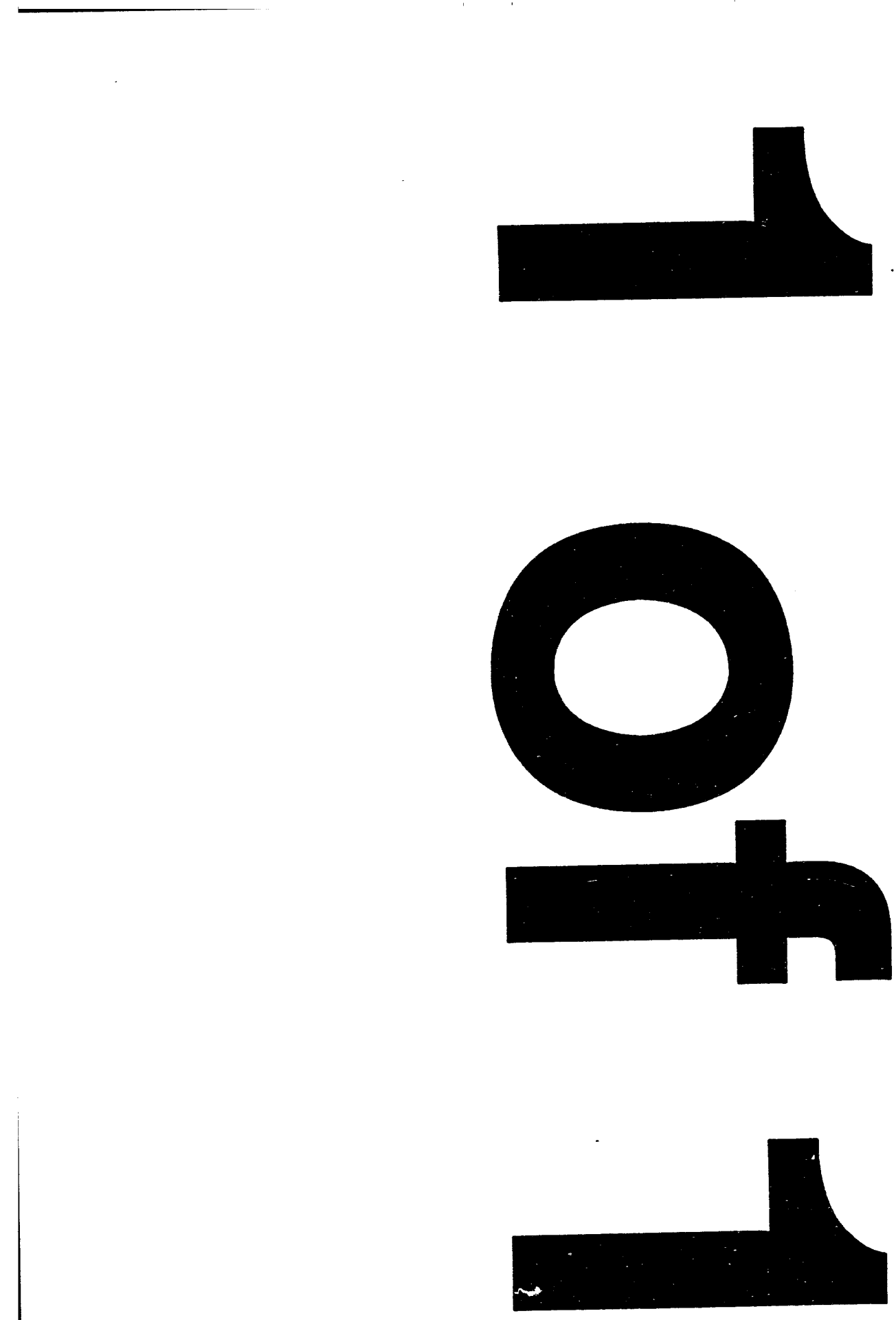
.2

\section{GLASS TEMPERATURES IN FREE-STANDING CANISTERS (U)}

by

B. J. Hardy

Savannah River Site

Aiken, South Carolina 29808

S. J. Hensel

DOE Contract No. DE-AC09-89SR18035

This paper was prepared in connection with work done under the above contract number with the U.S.

Department of Energy. By acceptance of this paper, the publisher and/or recipient acknowledges the U. S. Government's right to retain a nonexclusive, royalty-free license in and to any copyright covering this paper, along with the right to reproduce and to authorize others to reproduce all or part of the copyrighted paper. 


\section{DISCLAIMER}

This report was prepared as an account of work sponsored by an agency of the United States Government. Neither the United States Government nor any agency thereof, nor any of their employees, makes any warranty, express or implied, or assumes any legal liability or responsibility for the accuracy, completeness, or usefulness of any information, apparatus, product, or process disclosed, or represents that its use would not infringe privately owned rights. Reference herein to any specific commercial product, process, or service by trade name, trademark, manufacturer, or otherwise does not necessarily constitute or imply its endorsement, recommendation, or favoring by the United States Government or any agency thereof. The views and opinions of authors expressed herein do not necessarily state or reflect those of the United States Government or any agency thereof.

This report has been reproduced directly from the best available copy.

Available to DOE and DOE contractors from the Office of Scientific and Technical Information, P. O. Box 62, Oak Ridge, TN 37831; prices available from (615) $576-8401$.

Available to the public from the National Technical Information Service, U. S. Department of Commerce, 5285 Port Royal Rd., Springfield, VA 22161 
WSRC-TR-93-520

REV. 0

Keywords: Waste-Eorm Temperatures DWPF Glass Temperature

Retention: Permanent

October 4,1993

TO: M. J. Plodinec, 773-A

S. L. Marra, 704-15S

FROM: B. J. Hardy, 773-64A

S. J. Hensel, 773-42A

\section{Glass Temperatures in Free Standing Canisters (U)}

CC: E. W. Holtzscheiter, 773-A

J. R. Pelfrey, 773-42A

D. A. Crowley, 704-1T

M. D. Boersma, 704-T

C. T. Randall, 704-T

F. J. Leach, 773-A

H. H. Elder, 704-S

A. A. Ramsey, 704-15S

G. J. Hutchens, 773-64A

J. W. Jerrel, 773-42A

N. E. Bibler, 773-A

J. E. Ortaldo, 704-S

J. A. Gentilucci, 704-S

L. F. Landon, 704-T

J. T. Carter, 740-25S

P. E. Lowe, 773-42A

W. T. Goldston, 704-S

J. E. Sproul1, 704-S

S. J. Hensel, 773-42A

C. Payne, 704-24S

Technical Information Mangement, 703-43A 
OSR 3-4A-W (MEV 1-89)

cc:

\author{
E. W. Holtzscheiter, 773-A \\ J. R. Pelfrey, 773-42A \\ D. Crowley, 704-1T \\ M. D. Boersma, 704-T \\ C. T. Randall, 704-T \\ F. J. Leach, 773-A \\ J. T. Carter, 704-25S \\ W. T. Goldston, 704-S \\ A. A. Ramsey, 704-15S \\ G. J. Hutchens, 773-64A
}
N. E. Bibler, 773-A
J. F. Ortaldo, 704-S
J. A. Gentilucci, 704-S
C. Payne, 704-24S
L. F. Landon, 704-T
P. E. Lowe, 773-42A
H. H. Elder, 704-S
J. F. Sproull, 704-S
J. W. Jerrell, 773-42A
TIM, 703-43A

October 4, 1993

TO:

M. J. Plodinec, 773-A

S. L. Marra, 704-15S

FROM: $\quad$ B. J. Hardy, 773-64A

S. J. Hensel, 773-42A \&. \&.

SUBJECT: Glass Temperatures in Free Standing Canisters

TECHNICAL REVIEWERS:

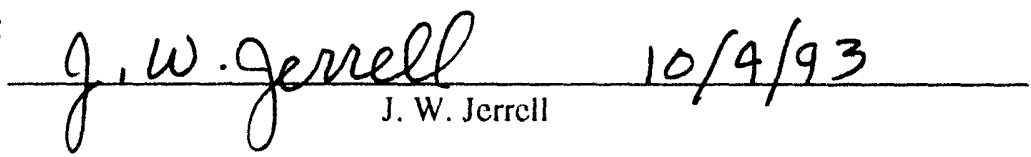

\title{
INTRODUCTION
}

The waste-forms produced by the Defense Waste Processing Facility (DWPF) are subject to the requirements of the Waste Acceptance Product Specifications (WAPS). The WAPS sets the maximum post cooldown temperature of the waste-form glass at $400^{\circ} \mathrm{C}{ }^{1}$ This criterion must be satisfied for the ambient conditions and heat generation rates expected for the waste-forms.

As part of the work described in task plan, WSRC-RP-93-1177, Rev. 0, $;$ computer model was used to calculate the maximum glass temperatures in free stancling wasteforms for a variety of ambient temperatures and heat generation rates. 


\section{MODEL DESCRIPTION}

\section{Canister Model}

The heat conduction code P/THERMAL ${ }^{2}$ was used to model waste-form heat transfer in two dimensional cylindrical coordinates, $r$ and $z$. The heat transfer at the surface of the canister was assumed to result from natural convection alone, as would be expected for a free standing canister. The natural convection boundary conditions were applied to the sides of the canister and the top and bottom were conservatively assumed to be insulated. The Nusselt number correlation used was ${ }^{3}$

$$
\mathrm{Nu}=0.21 \mathrm{Ra}^{0.4}
$$

The canisters were filled to $85 \%$ of the total height with glass (100 in. measured from the bottom). The void between the top of the glass and the upper part of the canister is filled with air and water vapor. The nominal dimensions and geometry of a DWPF waste-form were used to build the model. The steel canisters were modeled with the thermal properties of 304 stainless steel, which was $3 / 8$ in. thick in the cylindrical portion adjacent to the glass and $1 / 2$ in. thick at the top and bottom. The thermal properties of TDS glass were used and are listed in Table $1 .{ }^{4}$ It should be noted that the glass thermal conductivity used in all calculations was that of high iron glass, which was conservatively assumed to have $\sim 2 / 3$ of the thermal conductivity obtained from Table 1 . The properties of the 304 stainless steel were obtained from the P/THERMAL materials library and the canister dimensions are given in Reference 5.

P/THERMAL does not calculate convection processes, rather it only uses supplied convection boundary conditions. Therefore, heat transfer through the gas space at the top of the canister was by conduction only.

As the isotopes contained in the glass undergo radioactive decay, some of the emitted radiation interacts with the atoms in the waste-form and is transformed into heat. The attenuation of radiation thus results in a volumetric heat (or energy) source. The principal radiation emitted by isotopic decay is gamma radiation. Gamma radiation has a relatively long mean free path and is best attenuated by materials of high atomic weight. Therefore, the fraction of gamma radiation attenuated in the steel canister is a matter of concern.

Rather than calculate the distribution of gamma radiation between the glass and the steel canister, scoping calculations were performed. The energy deposition due to radioactive decay was assumed to be uniform and to take place either in the glass or in the cylindrical part of the steel canister adjacent to the glass. That is, when heat generation is assumed to occur in the steel, it takes place in the steel wall from the bottom of the canister up to 100 in. A total canister heat generation rate of 460 watts per canister was assumed in the GWSB design basis. The maximum glass temperatures obtained from these calculations will be representative of the most conservative case.

Additional details of these calculations are available in Reference 6. 


\section{RESULTS AND CONCLUSIONS}

The results of the P/THERMAL calculations are presented in Table 2. In these calculations the energy was assumed to be uniformly deposited in one of two regions, the glass or the steel cylinder adjacent to the glass. In Table 2 the location of energy deposition is specified according to the region in which the energy is deposited. The maximum glass temperatures are the maximum temperatures occurring at any location in the glass. Ambient temperatures of 100,50 and $0^{\circ} \mathrm{F}\left(37.78,-17.78\right.$ and $\left.10^{\circ} \mathrm{C}\right)$ were used in the calculations.

From Table 2 it can be seen that in all cases the deposition of energy in the glass yields higher maximum glass temperatures than energy deposition in the steel. Conservatively assuming energy deposition only in the glass and the ambient temperature to be $37.78{ }^{\circ} \mathrm{C}$ $\left(100^{\circ} \mathrm{F}\right)$, the glass temperature limit of $400^{\circ} \mathrm{C}$ is not exceeded for heat generation rates which are three times the 460) watts per canister used as the design basis for the GWSB. Also, the glass temperature profile is flatter if the energy is deposited in the steel than if the energy is deposited in the glass

\section{REFERENCES}

1. Office of Environmental Restoration and Waste Management. Waste Acceptance Product Specifications for Vitrified High-Level Waste Forms. USDOE Document EM-WAPS , Rev. (), U. S. Department of Energy, Germantown, MD (1993).

2. PITHERMAL Manual, version 2.6, March 1993, PDA Engineering, Costa Mesa, CA.

3. F. P. Incropera, D. P. DeWitt. Fundamentals of Heat Transfer. John Wiley \& Sons.

4. L. D. Pye. The Physical and Thermal Properties of Simulated Nuclear Waste Glasses and Their Melts. E. I. Du Pont de Nemours \& Co. document, submitted under subcontract AX 535001h, February 1985.

$5 \quad$ R. G. Baxter. Defense Waste Processing Facility Wasteform and Canister Description. E. I. Du Pont de Nemours \& Co. document, DP-1606, Rev. 2 (1988).

6. S. J. Hensel. Laboratory Notebook. Westinghouse Savannah River Company Document, NB-93-179 (1993). 
TABLE 1

Assumed Glass Thermal Properties (TDS Glass) ${ }^{4}$

\begin{tabular}{|c|c|}
\hline Property & Value \\
\hline Density & $2.43 \frac{\mathrm{g}}{\mathrm{cm}^{3}}$ at $23^{\circ} \mathrm{C}$ \\
Thermal Diffusivity & $0.0031 \frac{\mathrm{cm}^{2}}{\mathrm{sec}}$ at $150^{\circ} \mathrm{C}$ \\
Specific Heat Capacity & $0.20 \frac{\mathrm{cal}}{\mathrm{g}{ }^{\circ} \mathrm{C}}$ at $100^{\circ} \mathrm{C}$ \\
\hline
\end{tabular}

TABLE 2

P/THERMAL Calculations for Glass and Canister Air Temperatures

\begin{tabular}{|c|c|c|c|c|c|}
\hline Case No. & $\begin{array}{l}\text { Location of } \\
\text { Encrgy } \\
\text { Deposition }\end{array}$ & $\begin{array}{c}\text { Ambient } \\
\text { Temp. } \\
\left({ }^{\circ} \mathrm{C}\right)\end{array}$ & $\begin{array}{c}\text { Total } \\
\text { Power } \\
\text { (Watts) } \\
\end{array}$ & $\begin{array}{l}\text { Max. Glass } \\
\text { Temp }\left({ }^{\circ} \mathrm{C}\right)^{*}\end{array}$ & $\begin{array}{l}\text { Location of Max. Glass } \\
\text { Temperature }\left({ }^{\circ} \mathrm{C}\right)\end{array}$ \\
\hline 1 & Glass & 37.78 & 460 & 132 & CLA8 in.fromboutom \\
\hline 2 & Glass & 37.78 & 1280 & 301 & CLA8 in.fromboutom \\
\hline 4 & Steel & 37.78 & 460 & 64 & $\begin{array}{l}\text { (Autcredge of glass belowancrgy } \\
\text { dęxxitionrogion in stecl }\end{array}$ \\
\hline 5 & Steel & -17.78 & 460 & 5 & $\begin{array}{l}\text { Qtter dige of glass belowenergy } \\
\text { dquxsitionnegion in steel }\end{array}$ \\
\hline 6 & Steel & -17.78 & 153.3 & -8 & $\begin{array}{l}\text { Outurexdge of glaxs belowenergy } \\
\text { depnsitionnegion in stect }\end{array}$ \\
\hline 7 & Glass & -17.78 & 460 & 73 & CL50 in.frombottom \\
\hline 8 & Glass & -17.78 & 153.3 & 15 & ClA6in.fromboutom \\
\hline 9 & Glass & 10 & 460 & 111 & CLA6 in.frombotum \\
\hline 10 & Steel & 10 & 460 & 43 & $\begin{array}{l}\text { Ancrodge of glass belowencrgy } \\
\text { depositionnegion in stocl }\end{array}$ \\
\hline
\end{tabular}

* temperature rounded to most conservative integer value 
WSRC-TR-93-520

Revision 0

DISTRIBUTION :

M. K. Andrews, 773-A

D. C. Beam, 773-A

N. E. Bibler, 773-A

D. F. Bickford, 773-A

S. A. Budenstein, 704-1T

J. T. Carter, 704-25S

C. A. Cicero, 773-A

C. L. Crawford, 773-A

D. A. Crowley, 704-1T

E. F. Duhn, 773-A

H. H. Elder, 704-S

D. M. Ferrara, 773-A

J. A. Gentilucci, 704-S

W. T. Goldston, 704-S

B. C. Ha, 773-A

J. R. Harbour, 773-43A

B. J. Hardy, 773-64A

S. J. Hensel, 773-42A

D. T. Herman, 773-64A

E. W. Holtzscheiter, 773-A

G. J. Hutchens, 773-64A

C. M. Jantzen, 773-A

J. W. Jerrel, 773-42A

A. L. Kielpinski, 773-11A

L. F. Landon, 704-T

F. J. Leach, 773-A

P. E. Lowe, 773-42A

S. L. Marra, 704-15S

K. E. Mottel, 773-43A

J. F. Ortaldo, 704-S

C. H. Payne, 704-24S

J. R. Pelfrey, 773-42A

M. J. Plodinec, 773-A

A. A. Ramsey, 704-15S

W. G. Ramsey, 773-A

C. T. Randall, 704-T

R. F. Schumacher, 773-42A

J. F. Sproull, 704-S

Technical Information Management, 703-43A 

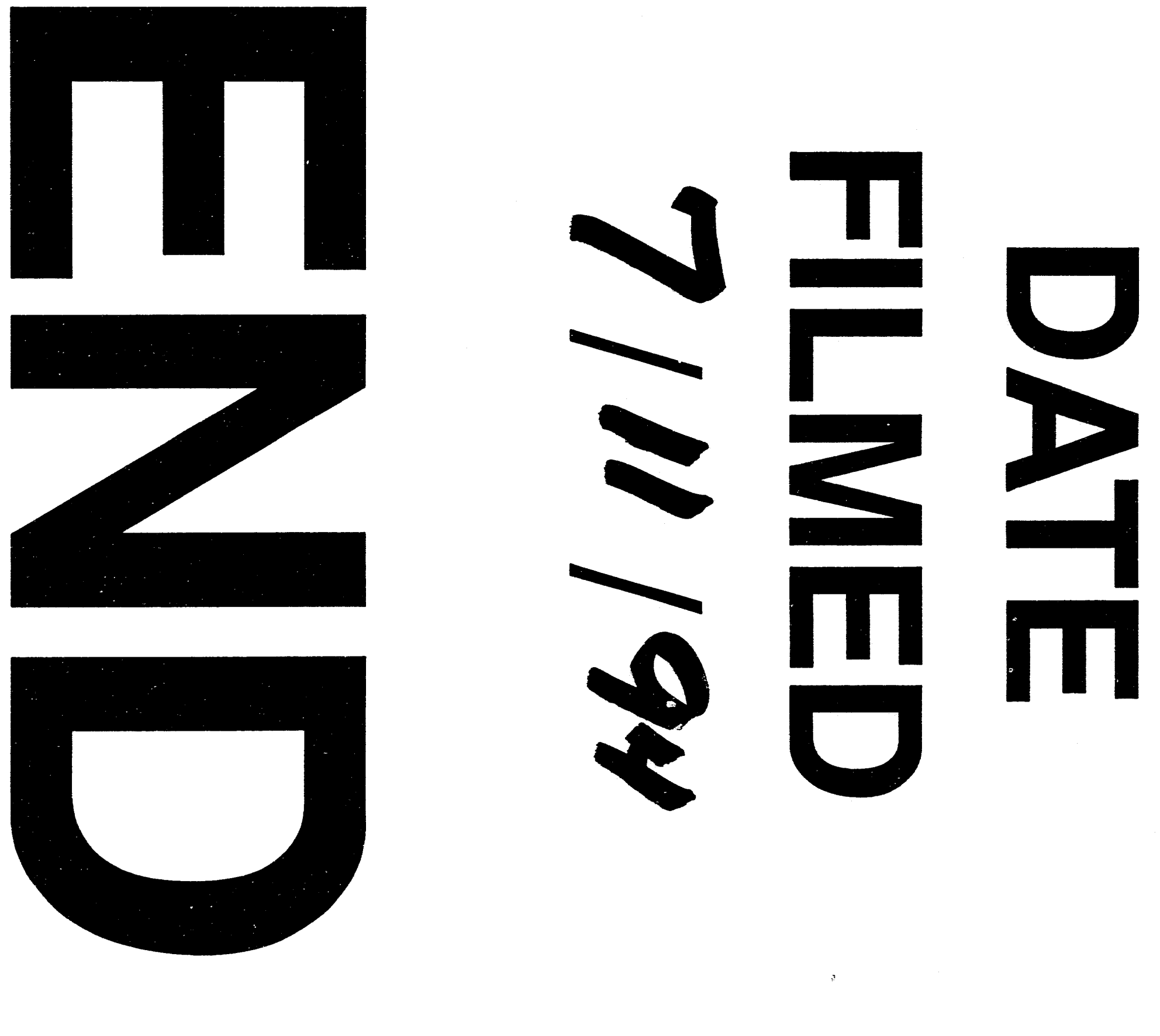

$+$

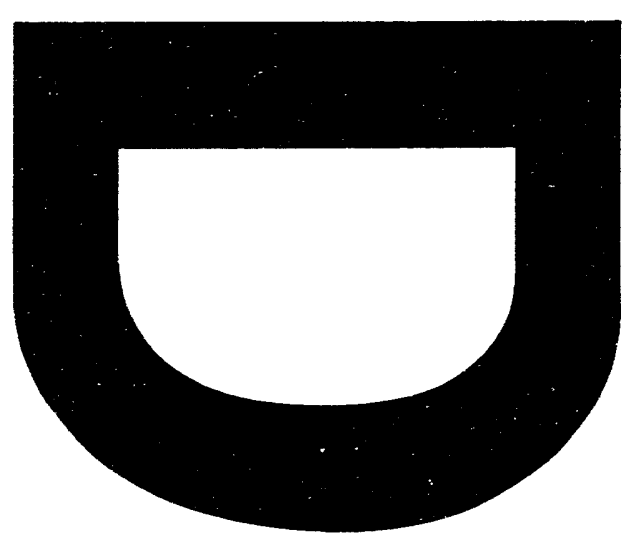


